Acta vet. scand. $1976,17,271 \longrightarrow 278$.

From the Municipal Laboratory, Odense, Denmark.

\title{
THE INCIDENCE OF ANTIBIOTIC RESISTANCE AMONG COLIFORM BACTERIA ISOLATED FROM FOOD
}

\author{
By \\ Henry Sфgaard
}

\begin{abstract}
SØGAARD, HENRY: The incidence of antibiotic resistance among coliform bacteria isolated from food. Acta vet. scand. 1976, 17, 271278. - Three-hundred-and-seventy-eight strains of coliform bacteria were isolated from specimens of commonly sold milk and food products. Klebsiella and Enterobacter spp. were predominating. Resistance to sulphonamides, streptomycin, and chloramphenicol occurred in only 5, 1, and 2 strains, respectively. No tetracycline-resistant strains were found. Two-hundred-and-two strains $(54 \%)$ were resistant to ampicillin. In genetic crosses with a sensitive strain of E. coli K 12 W 3132 transmissible $R$ factors could not be demonstrated in any of the resistant coliform strains.

It is concluded that food is not a significant source of antibiotic resistant enteric bacteria. It may, however, be suggested that food is a source of potentially pathogenic gram-negative bacteria which points out the importance of strict hygienic surveillance of food production.
\end{abstract}

coliforms; antibiotic resistance; food hygiene.

Antibiotic-resistant strains of enteric gram-negative bacteria can be isolated from a majority of humans not receiving treatment with antimicrobial drugs (Datta 1969, Moorhouse 1969, Jonsson 1972, Shaw et al. 1973, Sфgaard 1975). In a quantitative study, it was demonstrated that in 95 persons, enteric bacteria resistant to sulphonamides, tetracyclines, and streptomycin were excreted at a mean frequency of $10^{-3}$ to $10^{-4}$ (Søgaard).

The present situation no doubt has emerged as a result of widespread use of antibiotics in hospitals, general medical practice, veterinary practice, and in livestock production. This has brought about selection of $\mathrm{R}$ factor carrying strains. The routes by which such strains are disseminated throughout the human population is not well understood.

It has been demonstrated that humans in close contact with farm animals may acquire resistant enteric organisms from the animals (Linton et al. 1972, Wells \& James 1972). 
Smith (1969) demonstrated that in a human volunteer, $R$ factors from bovine $\mathrm{E}$. coli strains could be transferred in vivo to the resident bowel flora.

In Denmark only a minor proportion of the population is exposed to direct acquisition of resistant strains from farm animals. Another possible way of spreading of such organisms would be ingestion through food. The present study was undertaken in order to investigate the incidence of antibiotic resistance among coliform bacteria isolated from a wide range of common food products.

\section{MATERIALS AND METHODS}

\section{Collection of food specimens}

The bacterial strains included in the study were all isolated from specimens of pasteurized milk products and other food products collected for routine bacteriological examination in Odense Municipal Laboratory. Collection of specimens was done aseptically from factories and retail shops by the laboratory staff. During transportation and storage until examination, the specimens were kept under refrigeration.

\section{Isolation of coliform bacteria}

Initially, $5 \mathrm{~g}$ of specimen was weighed out in sterile Vortex beakers; $45 \mathrm{ml}$ of quarter-strength Ringer solution was added and a $10^{-1}$ suspension was prepared by means of a MSE homogenizer (Measuring \& Scientific Equipment Ltd., Sussex, England). One $\mathrm{ml}$ of the suspension and of appropriate decimal dilutions were seeded in melted Violet Red Bile Agar (Difco B 12). After solidification, the agar was sealed with $3-4 \mathrm{ml}$ of melted medium. Plates were incubated overnight at $37^{\circ} \mathrm{C}$. From random samples with typical lactose-fermenting colonies, one colony was picked for identification and examination for antibiotic resistance. This part of the study was carried out during the author's employment at the Institute of Medical Microbiology, Odense University.

\section{Identification of strains}

After isolation in pure culture the strains were identified by the following biochemical tests: growth in semi-solid agar, Voges- 
Proskauer reaction, indole production, fermentation of glucose and malonate, gelatin liquefaction, $\mathrm{H}_{2} \mathrm{~S}$-production (Lautrop 1956), and lysine and ornithine decarboxylase determination according to M $\phi$ ller (1955). A total of 378 strains were examined, of which 44 could not be conclusively grouped even after more detailed biochemical testing.

\section{Test for antibiotic sensitivity}

Broth cultures of the strains were prepared in nutrient broth and were incubated overnight at $37^{\circ} \mathrm{C}$. The cultures were diluted $1: 100$, and $0.1 \mathrm{ml}$ of the dilutions were spread evenly on $10 \%$ horse blood agar. Tablets (Neo-sensitabs R, Rosco, Tåstrup, Denmark) containing the following antibiotics: sulphonamide $(\mathrm{Su})$, tetracycline $(\mathrm{T})$, streptomycin (S), chloramphenicol (C), and ampicillin (A) were placed on the plates which were incubated overnight at $37^{\circ} \mathrm{C}$. According to the diameters of the zones of inhibition, the strains were classified as sensitive, moderately sensitive, relatively resistant, or resistant. Strains classified as relatively resistant were included in the group of resistant strains. This group therefore includes strains with the following or higher minimal inhibitory concentrations $(\mu \mathrm{g} / \mathrm{ml})$ : Su 15, T 4, S 16, C 16, and A 4. Strains resistant to one or more of the antibiotics in question were tested for transmissible $R$ factors.

\section{Test for transmissible $R$ factors}

A nalidixic acid resistant mutant of E. coli K 12 W 3132 was used as recipient strain in genetic crosses with the resistant strains. W 3132 is an auxothroph strain requiring methionine for growth, and it is sensitive to the five antibiotics in question. Its competence as recipient of $\mathbf{R}$ factors has been demonstrated in previous experiments ( $\$ \phi$ gaard 1975).

Each donor strain and the recipient strain were grown separately overnight in nutrient broth; $0.02 \mathrm{ml}$ of donor cultures was transferred to $10 \mathrm{ml}$ of fresh broth together with $0.1 \mathrm{ml}$ of the recipient cultures. The mating cultures were incubated overnight at $37^{\circ} \mathrm{C} ; 0.1 \mathrm{ml}$ was then spread on Conradi-Drigalski agar plates containing $25 \mu \mathrm{g} / \mathrm{ml}$ of nalidixic acid plus either of the antibiotics to which the potential donor strains were resistant. The concentrations of drugs in the selection media were as fol- 
T a b le 1. Distribution of lactose fermenting species of Enterobacteriaceae isolated from food products.

\begin{tabular}{|c|c|c|c|c|c|c|c|c|c|c|c|c|}
\hline Species & 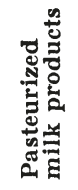 & 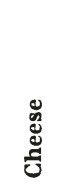 & 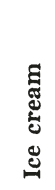 & 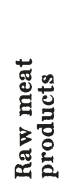 & 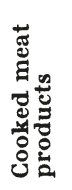 & 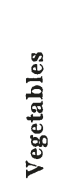 & $\begin{array}{l}\vec{E} \\
\overrightarrow{0} \\
\overrightarrow{0} \\
\overrightarrow{0}\end{array}$ & 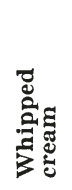 & 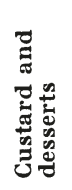 & 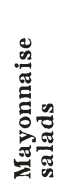 & 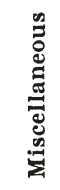 & Total * \\
\hline E. coli & 25 & 6 & 1 & 4 & 10 & 2 & 3 & 6 & 3 & 4 & 6 & $7.0(18.5)$ \\
\hline Ent. cloacae & 28 & - & 8 & - & 16 & 5 & 4 & 8 & 15 & 3 & 8 & $95(25.1)$ \\
\hline Ent. aerogenes & 3 & - & - & - & 5 & 一 & - & - & - & 3 & 3 & $14(3.7)$ \\
\hline Kl. oxitoca & 25 & - & 12 & - & 7 & - & 3 & 14 & 6 & 9 & 1 & $77(20.4)$ \\
\hline Kl. pneumoniae & 9 & 2 & 2 & - & 4 & 5 & 1 & 2 & 4 & 5 & 4 & $38(10.1)$ \\
\hline Kl. ozoenae & - & - & - & - & - & - & - & - & 1 & 1 & - & $2(0.5)$ \\
\hline C. freundii & 28 & - & 2 & - & 2 & 2 & - & 1 & 1 & 1 & - & $37(9.8)$ \\
\hline Hafnia alvei & - & - & - & - & - & - & - & - & 1 & - & - & $1(0.3)$ \\
\hline Not typable & 23 & - & 8 & - & 6 & - & - & 3 & 一 & - & 4 & 44 (11.7) \\
\hline Total & 141 & 8 & 33 & 4 & 50 & 14 & 11 & 34 & 31 & 26 & 26 & 378 \\
\hline
\end{tabular}

* Figures in brackets indicate percentages.

lows: sulphadimidine $100 \mu \mathrm{g} / \mathrm{ml}$ (Conradi-Drigalski agar without peptone), tetracycline $10 \mu \mathrm{g} / \mathrm{ml}$, streptomycin $20 \mu \mathrm{g} / \mathrm{ml}$, chloramphenicol $20 \mu \mathrm{g} / \mathrm{ml}$, and ampicillin $10 \mu \mathrm{g} / \mathrm{ml}$. As control, donor and recipient cultures were plated separately on selection media.

\section{RESULTS}

In Table 1 the coliform strains are listed according to the type of food product from which they were isolated. It appears that Enterobacter spp. and Klebsiellae occurred more frequently than E. coli. These findings clearly indicate that contamination of food with coliforms is not primarily of faecal origin. The distribution of the different species of bacteria seems to be quite uniform regardless of type of product.

The incidence of antibiotic resistance among the 378 strains is shown in Table 2. Resistance to sulphonamides, streptomycin, and chloramphenicol occurred only rarely $(5,1$, and 2 strains, respectively), whereas 202 strains were resistant to ampicillin (54\%). This is not surprising since a number of coliform bacteria other than E. coli are inheritably resistant to this drug.

Six strains only were found with resistance genes other than ampicillin. The resistance patterns of these strains are listed in 
Table 3. Transfer of $R$ factors could not be demonstrated in any of these strains. This was not the case either in strains singly resistant to ampicillin.

T a b l e 2. Incidence of antibiotic resistance in strains of lactosefermenting Enterobacteriaceae isolated from food products.

\begin{tabular}{|c|c|c|c|c|c|c|}
\hline \multirow[t]{2}{*}{ Species } & \multicolumn{5}{|c|}{ Number of strains resistent to } & \multirow{2}{*}{$\begin{array}{l}\text { Total number } \\
\text { of strains }\end{array}$} \\
\hline & SU & $\mathbf{T}$ & $\mathbf{s}$ & C & $\mathbf{A}$ & \\
\hline E. coli & 0 & 0 & 0 & 0 & 7 & 70 \\
\hline Ent. cloacae & 1 & 0 & 1 & 1 & 57 & 95 \\
\hline Ent. aerogenes & 0 & 0 & 0 & 0 & 2 & 14 \\
\hline Kl. oxitoca & 1 & 0 & 0 & 0 & 61 & 77 \\
\hline Kl. pneumoniae & 1 & 0 & 0 & 1 & 39 & 38 \\
\hline Kl. ozoenae & 0 & 0 & 0 & 0 & 0 & 2 \\
\hline C. freundii & 0 & 0 & 0 & 0 & 17 & 37 \\
\hline Hafnia alvei & 1 & 0 & 0 & 0 & 1 & 1 \\
\hline Not typable & 1 & 0 & 0 & 0 & 18 & 44 \\
\hline Total & 5 & 0 & 1 & 2 & 202 & 378 \\
\hline
\end{tabular}

T a ble 3. Resistance patterns of 6 strains resistant to other antibiotics than ampicillin.

\begin{tabular}{lcc}
\hline Species & $\begin{array}{c}\text { Resistance } \\
\text { pattern }\end{array}$ & $\begin{array}{c}\text { Transmissible } \\
\text { R factor }\end{array}$ \\
\hline $\begin{array}{l}\text { Ent. cloacae } \\
\text { Ent. cloacae }\end{array}$ & Su S A & - \\
Kl. pneumoniae & C & - \\
Kl. oxitoca & Su C A & - \\
Hafnia alvei & Su A & - \\
Not typed & Su A & - \\
\hline
\end{tabular}

\section{DISCUSSION}

The present study has revealed that in Denmark, contamination of milk and food products with coliform bacteria does not represent a significant source of antibiotic resistant organisms. It should be emphasized, however, that most strains were isolated from heat-treated products. Presence of coliforms in such products is therefore likely to reflect the environmental flora of processing plants. 
It is noteworthy that among $\mathbf{7 0}$ strains of $\mathbf{E}$. coli no resistance was found to sulphonamides, tetracycline, streptomycin, or chloramphenicol. Heever (1972) examined 41 E. coli strains from minced meat and milk. Of these $36.5 \%$ were resistant. Moorhouse et al. (1969) isolated resistant E. coli strains from 17 out of 27 sausages. They suggested that the strains originated in the intestines used for the sausages. Poláková et al. (1972) found 521 E. coli strains out of 772 isolated from milk and meat products to be resistant to one or more antibiotics. Thinty of the resistant strains harboured transmissible $R$ factors. In a study of hospital food, Cooke et al. (1971) isolated $109 \mathrm{E}$. coli strains from medium that did not contain antibiotics. Twenty strains were resistant. A similar proportion of resistance was found by Jones (1971) who examined $127 \mathrm{E}$. coli strains also isolated on non-selective media from retail milk samples. Fifteen of these strains were resistant.

In most people, E. coli is the predominant species of the aerobic intestinal flora. Other members of the family Enterobacteriaceae, however, can be isolated from a certain proportion. In a study from a hospital ward (Sфgaard 1975), it was found that Klebsiellae and Enterobacter spp. were excreted by $32 \%$ and $17 \%$, respectively, of hospital patients on their admission. These organisms are potential pathogens, especially in debiliated hospital patients, and their role in nosocomial infections has increased during recent years (Bush et al. 1965). The present study has shown that food may well be a source of potentially pathogenic gram-negative bacteria. This also points out the importance of strict hygienic surveillance of food production.

\section{ACKNOWLEDGEMENT}

The author wants to thank the Staff of Odense Municipal Laboratory for collecting the bacterial strains. The skillful technical assistance of Mrs. Rita Kruse is highly appreciated.

\section{REFERENCES}

Bush, I. M., L. A. Orkin \& J. Winter: An eleven-year study of urinary bacterial cultures in a total in-patient hospital population. J. Urol. (Baltimore) 1965, 94, 168-171.

Cooke, E. M., A. L. Breaden, R. A. Shooter \& S. M. O'Farrell: Antibiotic sensitivity of Escherichia coli isolated from animals, food, hospital patients, and normal people. Lancet 1971, 2, 8-10. 
Datta, N.: Drug resistance and $\mathrm{R}$ factors in the/bowel bacteria of London patients before and after admission to hospital. Brit. med. J. $1969,2,407-411$.

Van den Heever, L. W.: Antibiotic resistance and R-factors in Escherichia coli from calves, meat, and milk. J. S. Afr. vet. med. Ass. 1972, 43, 71-75.

Jones, A. M.: Escherichia coli in retail samples of milk and their resistance to antibiotics. Lancet 1971, 2, 347-350.

Jonsson, M.: Antibiotic resistance and $\mathbf{R}$ factors in gram-negative bacteria. Scand. J. infect. Dis. 1972, suppl. 5.

Lautrop, $H$. .: Gelatin-liquefying Klebsiella strains (Bacterium oxytocum Flügge). Acta path. microbiol. scand. 1956, 39, 1207-1212.

Linton, K. B., P. A. Lee, M. H. Richmond \& W. A. Gillespie: Antibiotic resistance and transmissible $\mathrm{R}$-factors in the intestinal coliform flora of healthy adults and children in an urban and a rural community. J. Hyg. (Lond.) 1972, 70, 99-104.

Moorhouse, E. C.: Transferable drug resistance in enterobacteria isolated from urban infants. Brit. med. J. 1969, 2, 405-406.

Moorhouse, E. C., M. F. O'Grady \& M. F. O'Connor: Isolation from sausages of antibiotic-resistant Escherichia coli with $\mathrm{R}$ factors. Lancet $1969,2,50-52$.

Møller, V.: Simplified tests for some amino acid decarboxylases and for the arginine dihydrolase system. Acta path. microbiol. scand. $1955,36,158-172$.

Poláková, O., J. Janoušková, H. Huštavova, I. Stankovský \& V. Krcmery: Occurrence of Escherichia coli strains with multiresistance and transferable resistance to antibiotics in foodstuffs. J. Hyg. Epidem. (Praha) 1972, 16, 467-472.

Shaw, E. J., N. Datta, G. Jones, F. M. Marr \& W. J. B. Froud: Effect of stay in hospital and oral chemotherapy on the antibiotic sensitivity of bowel coliforms. J. Hyg. (Lond.) 1973, 71, 529-534.

Smith, $H$. W.: Transfer of antibiotic resistance from animal and human strains of Escherichia coli to resident E. coli in the alimentary tract of man. Lancet 1969, 1, 1174-1176.

$S \phi g a a r d, H .:$ Incidence of antibiotic resistance and transmissible $\mathbf{R}$ factors in the gram-negative bowel flora of hospital patients on admission. Scand. J. infect. Dis. 1975, 7, 253-258.

Wells, D. M. \& O. B. James: Transmission of infectious drug resistance from animals to man. J. Hyg. (Lond.) 1972, 70, $209-215$.

\section{SAMMENDRAG}

Hyppigheden af antibiotikaresistens blandt koliforme bakterier isoleret fra levnedsmidler.

378 stammer af koliforme bakterier blev isoleret fra prøver af konsummælk og andre levnedsmidler. Klebsiella- og Enterobacter-arter var de hyppigst forekommende. Resistens over for sulfonamider, streptomycin og kloramfenikol kunne kun påvises hos henholdsvis 5, 
1 og 2 stammer. Tetracyklinresistente stammer blev ikke fundet. 202 stammer $(54 \%)$ var resistente over for ampicillin. Ved krydsning med $\mathrm{E}$ coli $\mathrm{K} 12 \mathrm{~W} 3132$, der er følsom for de aktuelle antibiotika, kunne overførsel af $\mathrm{R}$ faktorer ikke påvises fra nogen af de resistente stammer.

Det konkluderes, at levnedsmidler ikke udg $\varnothing \mathrm{r}$ et betydende reservoir af antibiotikaresistente tarmbakterier. Unders $\varnothing$ gelsen har imidlertid vist, at levnedsmidler kan spille en rolle som kilde til potentielt patogene gramnegative bakterier. Dette understreger vigtigheden af en effektiv hygiejnisk kontrol med levnedsmiddelproduktion.

(Received April 7, 1976).

Reprints may be requested from: Odense kommunes laboratorium, Rugårdsvej 60, DK-5000 Odense, Denmark. 